\title{
Reassessment of threat status of Allium carolinianum Redouté (Amaryllidaceae)
}

\author{
Deepakshi Babbar ${ }^{1}$, Damini Sharma ${ }^{1,2}$, Kusum Upadhyay ${ }^{1,2}$, Mayank D. Dwivedi1 ${ }^{1,3}$ \\ and Sandeep Kumar Chauhan ${ }^{1}$ \\ ${ }^{1}$ Botanic Garden of Indian Republic, Botanical Survey of India, Noida - 201303, India \\ ${ }^{2}$ Mansarovar Global University, Bhopal - 462042, Madhya Pradesh, India \\ ${ }^{3}$ Corresponding author; e-mail: mayank_dwivedi10@yahoo.com
}

[Received 01.12.2020; Revised 17.12.2020; Accepted 21.12.2020; Published 31.12.2020]

\begin{abstract}
The present communication reassessed the threat status of Allium carolinianum Redouté (Amaryllidaceae) as its population is continuously declining due to different natural and anthropogenic pressures. Geocat online tool was used for the study of the geographical distribution of the species. The species is known to be distributed from Central Asia to Mongolia, and Trans Himalayan countries including India, which is less than five locations of occurrence all around the world (criteria B2(a), IUCN Red list,). Present study revealed the Area of occupancy (AOO) to be $284 \mathrm{Km}^{2}$ and, hence, the threat status of the species has been upgraded to Endangered (EN) category from Vulnerable (VU) $\left(<500 \mathrm{~km}^{2}, \mathrm{~B} 2\right.$ criteria) following IUCN recommendations. Additional measures such as land use land cover changes (LULC) were recorded as the studied land at many places have been converted to the agricultural land destroying the original habitat of the species (Criteria B2(b3)).
\end{abstract}

Key words: Allium carolinianum, Endangered, Himalaya, IUCN, AOO, EOO, GeoCat

\section{INTRODUCTION}

The threat reassessment of vascular plants is essential for conservation and maintenance of biodiversity (Mora et al. 2011; Trias-Blasi et al. 2017). Till date, 61,914 out of the 8.7 million species $(<1 \%)$ have been evaluated for their conservation status following Red List criteria (Bachman et al.2011). Re-evaluation of the taxa is crucial as it keeps on changing in due course of time.

Trans-Himalaya is one of the most remote and inaccessible regions of the world. Biogeographically, the Indian Trans-Himalayan zone is classified under 1A, 1B, 1C and 1D provinces (Kumar et al. 2017). Cold desert Trans-Himalaya of India occupies 98,980 sq Km (Srivastava 2010). It majorly includes Ladakh, Lahaul-Spiti valley and Kinnaur in Himachal Pradesh, Nelang and Mana Niti valley in Uttarakhand. The mesophytic and xerophytic patchy vegetation of this region mainly comprised of the plants with prostrate, thick, woolly, cushionlike, spiny plants with deep penetrating long roots and small and thick leaves (Srivastava \& Shukla 2015).

Allium carolinianum Redouté (Amaryllidaceae) is known to be distributed in Central Asia. This species is restricted to the mountains of the cold desert region with an altitude of $3000-$ $5000 \mathrm{~m}$ amsl (Figure 1). In 2015, the conservation status of this species was assessed as threatened (Srivastava \& Shukla 2015). However, it was not assigned any threat status by IUCN (2012) and, therefore, remained under the category "Not evaluated".

Moreover, the local people of Lahaul-Spiti valley and Ladakh harvest $A$. corolinianum for cooking purposes (Singh et al. 2007). Its leaves and bulbs are cooked as vegetable or used as a condiment (Murti 2001; Pandey et al. 2008; Singh et al. 2015; Aziz et al. 2020). Due to 


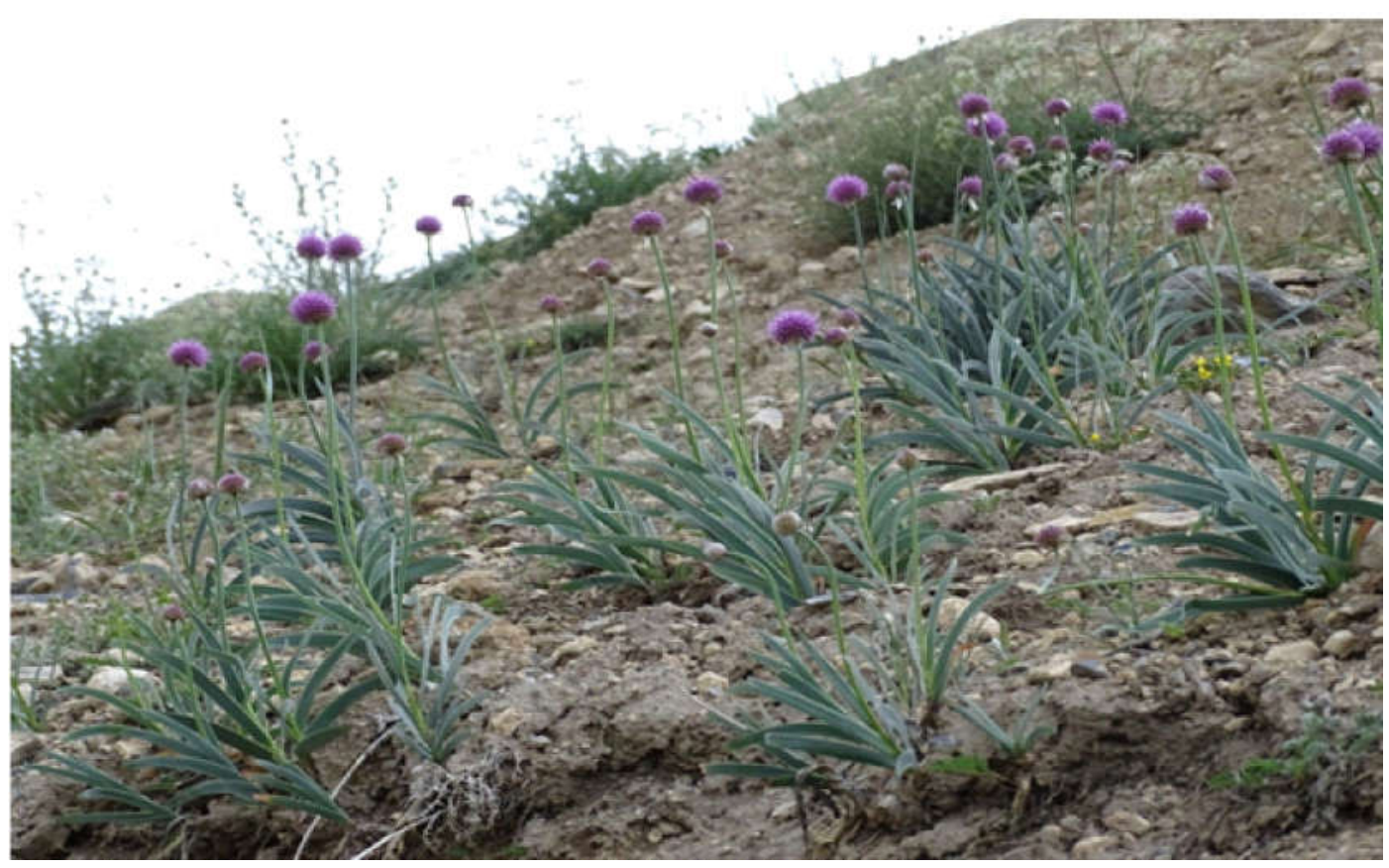

Figure 1: Habit and habitat of Allium carolinianum Redouté (Photographed at LahaulSpiti, Himachal Pradesh)

increasing demand of this species, and conversion of land into the agricultural field for cultivation, the species is fast disappearing from the natural habitats. Therefore, this study was undertaken to understand the threat status of this important plant species.

\section{MATERIALS AND METHODS}

The geographic distribution of the species can be understood using two measures i.e. Extent of occurrence (EOO) and Area of occurrence (AOO). GeoCat, online tool (http:// geocat.kew.org/) was used to assess and determine the spatial extent of the georeferenced data. The area of the cell size was taken as $2 \mathrm{~km}^{2}$ following IUCN recommendations. The geocoordinates for the A. carolinianum were taken from the online databases viz. iNaturalist (https:/ /www.inaturalist.org/), Flickr (https://www.flickr.com/about), GBIF (https://www.gbif.org/ ), field data, as well as from the herbarium specimens housed in ARUN, BSD, CAL, and DD. Before importing the coordinates into GeoCat the DMS (Degree Minute second) values were converted into the DD (Decimal degree) format.

\section{RESULTS AND DISCUSSION}

Our survey of the literature indicated the distribution of Allium carolinianum in several countries of Central Asia (Afghanistan, Kazakhstan, Kyrgyzstan, Tajikistan, Tibet, Uzbekistan and Xinjiang), Himalayas (Nepal, Pakistan, India) and Mongolia (Nasir 1975; Hara et al. 1978; Zhengyi and Raven 2000; Singh \& Sanjappa 2006). The population of A. carolinianum occurs in patches approximately up to $200 \mathrm{~m}^{2}$ and number of individuals in the mentioned area varies from 2 to148. (Sharma et. al., unpublished data). It can survive dry stony slopes, where bulbs of Allium spp. provide anchorage that helps them to withstand in the extreme environment. Our results showed that EOO area exceeds the area designated for the threatened categories $\left(<20,000 \mathrm{Km}^{2}\right.$ for vulnerable taxon) and fits within the category of 

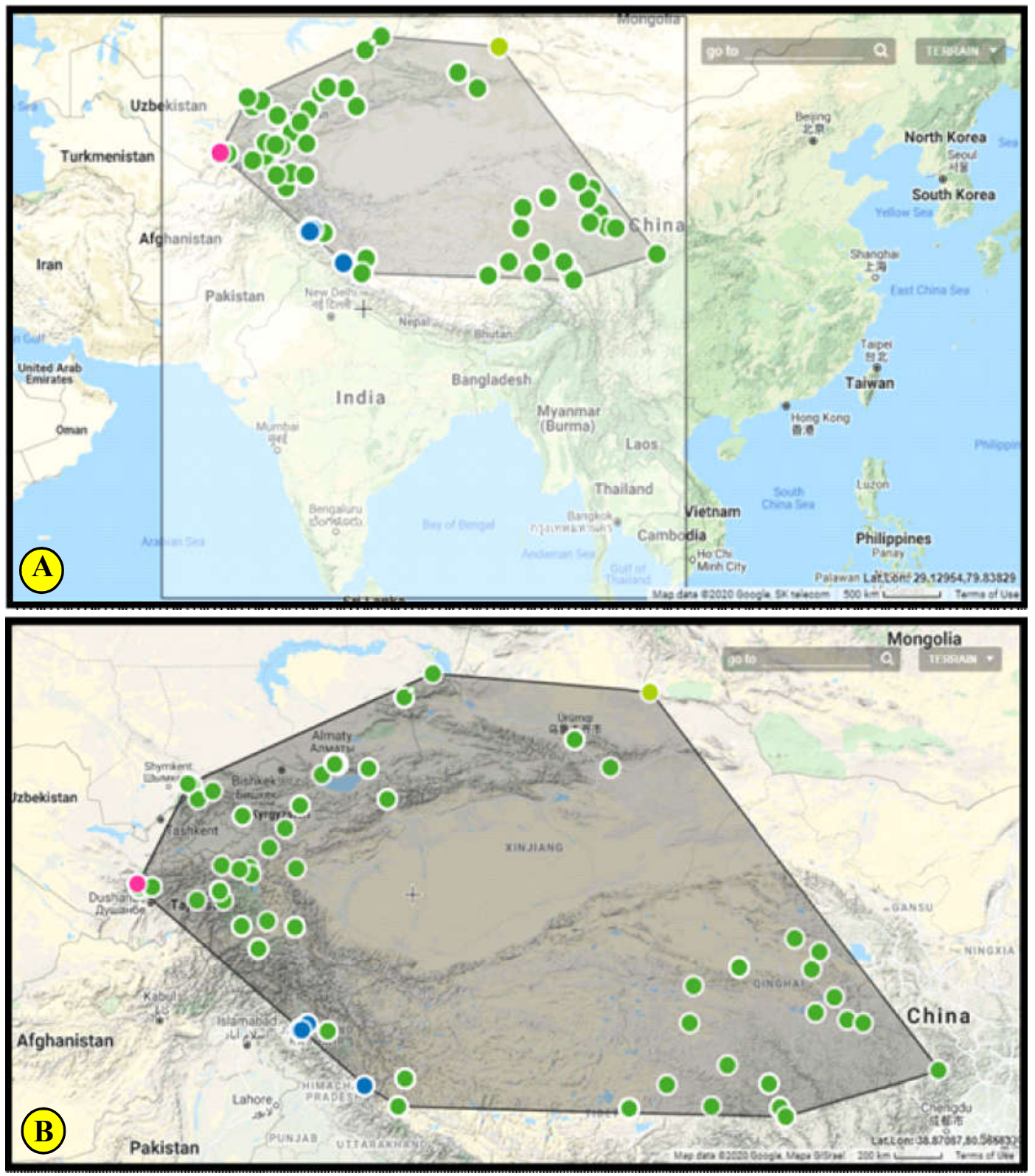

Figure 2: (A \& B): Geo co-ordinates developed from the herbarium study and field data showing Area of occupancy (AOO) and Extent of occurrence (EOO)

Least concern with an area of $3,413,054.059 \mathrm{~km}^{2}$. The AOO comes under the category 'Endangered' (EN) with an area of $284 \mathrm{~km}^{2}$.

Allium carolinianum is found to be endangered as it follows the criteria B of the IUCN red list. We found that out of criteria B1 and B2, our results indicated this taxon fitting under the $\mathrm{B} 2$ criteria as the AOO is less than $500 \mathrm{~km}^{2}$ (IUCN, 2012 criteria B). IUCN listed three more criteria for any species to be declared as endangered, for which our results showed subsistence for criteria B2 (a) and B2 (b3), as Figure 2 shows the occurrence of the taxon in Central Asia to Mongolia and Trans Himalayan countries including India which is less than five 
locations of occurrence all around the world (supports criteria B2 (a); Jain and Bhownik 2016). We also found a continuing decline of $A$. carolinianum population due to natural and anthropogenic interventions (Verma et al. 2008; supports B2(b3)). The extreme harsh climatic conditions with constantly blowing dry wind and heavy snowfall for over six months challenge the survival of the plant. Moreover, poor seedling vigour in this taxon also leads to low adaptability in new habitat (Verma et al. 2008). Our field investigation also noted that migratory livestock of cows, sheep, yaks, goats, donkeys, mules and other wild animals like wild ass and boars damage the vegetation by overgrazing.

\section{Acknowledgements}

Authors are thankful to the Director, Botanical Survey of India for support and facilities; the Ministry of Environment, Forest and Climate Change (MoEF\& CC), Government of India; New Delhi for providing financial support to this study (Project GBPNI/NMHS 2017 18/LG 03/570dt.26/02/2018). They sincerely express their gratitude to Prof. Arun K. Pandey and Dr Ritesh K. Choudhary for valuable comments which greatly improved the text.

\section{LITERATURE CITED}

Aziz, A.; Abbasi, A.M.; Ullah, Z. \& Pieroni, A. 2020. Shared but Threatened: The Heritage of Wild Food Plant Gathering among Different Linguistic and Religious Groups in the Ishkoman and Yasin Valleys, North Pakistan. Foods. 9, 601 doi: 10.3390/foods9050601.

Bachman, S.; Moat, J.; Hill, A.; de la Torre, J. \& Scott, B. 2011. Supporting Red List threat assessments with GeoCAT: geospatial conservation assessment tool. ZooKeys, 150: 117 126. doi: $10.3897 /$ zookeys.150.2109.

Hara, H.; Stearn, W.T. \& Williams, H.J. 1978. An Enumeration of the Flowering Plants of Nepal. Vol. I Trustees of British Museum, London. Pp. 1 - 154.

IUCN. 2012. IUCN Red List Categories and Criteria: Version 3.1. Second edition. Vol. IV Gland, Switzerland and Cambridge, UK. Pp. $1-32$.

Jain, A. \& Bhowmik, S. 2016. Tectonics and Evolution of the Trans-Himalayan Mountains and Nagaland Ophiolite Belt. Proceedings of the Indian National Science Academy. 82 (3): 617-624 doi: $10.16943 /$ ptinsa/2016/48471.

Ji, Z. \& Meerow A.W. 2000. Amaryllidaceae. In: Zhengyi, W. \& Raven, P.H. (eds.), Flora of China. Vol. XXIV. Missouri Botanical Garden Press, St. Louis. Pp:1-431.

Kumar, A.; Adhikari, B.S. \& Rawat, G.S. 2017. Biogeographic delineation of the Indian TransHimalaya: need for revision. Current Science 113 (6): 1032 - 1033.

Mora, C.; Tittensor, D.P.; Adl, S.; Simpson, A.G B. \& Worm, B. 2011. How Many Species Are There on Earth and in the Ocean? PLoS Biol. 9, e1001127.

Murti, S.K. 2001. Flora of Cold Deserts of Western Himalaya (Monocotyledons). Vol. I. Botanical Survey of India, Dehradun. Pp: 131-132.

Nasir, E. 1975. Flora of Pakistan. Vol. 83. Department of Botany, University of Karachi, Karachi. Pp. 1 - 31.

Negi, K.S. 2006. Allium species in Himalayas and their uses with special references to Uttaranchal. Ethnobotany 18: 53 - 66.

Pandey, A.; Tomer, A.K.; Bhandari, D.C. \& Pareek, S.K. 2008. Towards collection of wild relatives of crop plants in India. Genetic Resources and Crop Evolution. 55: 187 - 202. 
Singh, B.; Sultan, P.; Hassan, Q.P.; Gairola, S. \& Bedi, Y.S. 2015. Ethnobotany, Traditional Knowledge, and Diversity of Wild Edible Plants and Fungi: A case study in the Bandipora District of Kashmir Himalaya, India. Journal of Herbs, Spices and Medicinal Plants. 22(3): 1 - 32. DOI:10.1080/10496475.2016.1193833

Singh, K.N.; Lal, B.; Singh, R.D.; Todaria, N.P. \& Ahuja, P.S. 2007. Species richness, distribution pattern and conservation status of higher plants in the Spiti cold desert of Trans-Himalaya, India. International Journal of Biodiversity Science and Management 3: 223 - 233.

Singh, N.P. \& Sanjappa, M. (eds.). 2006. Alliaceae, Liliaceae, Trilliaceae \& Uvulariaceae Fascicles of Flora of India. Vol. XXIII. Botanical Survey of India, New Delhi. Pp. $1-134$.

Srivastava, S.K. 2010. Floristic diversity and conservation strategies in cold desert of western Himalaya, India. Botanica Orientalis- Journal of Plant Science 7: 18 - 25. doi: 10.3126/ botor.v7i0.4369.

Srivastava, S.K. \& Shukla, A.N. 2015. Flora of Cold Desert Western Himalaya, India. Vol. II. Botanical Survey of India, New Delhi. Pp. 5.

Trias-Blasi, A.; Gucel, S. \& Ozden, O. 2017. Current distribution and conservation status reassessment of the Cyprus Tulip (Tulipa cypria: Liliaceae), a new data from Northern Cyprus. Plant Biosystem. 151(3): 394 - 402.

Verma, V.D.; Pradheep, K.; Khar, A.; Negi, K.S. \& Rana, J.C. 2008. Collection and Characterization of Allium species from Himachal Pradesh. Journal of Plant Genetic Resource 21(3): $225-228$. 